\title{
Progesterone and Follicle Stimulating Hormone interact and promote goat preantral follicles survival and development in vitro ${ }^{1}$
}

\author{
Isabel B. Lima-Verde ${ }^{2 *}$, Maria H.T. Matos ${ }^{2}$, Juliana J.H. Celestino ${ }^{2}$, Rafael Rossetto ${ }^{2}$, \\ Khesller P.O. Name ${ }^{3}$, Sônia N. Báo ${ }^{3}$, Cláudio C. Campello² and José R. Figueiredo ${ }^{2}$
}

\begin{abstract}
Lima-Verde I.B., Matos M.H.T., Celestino J.J.H., Rossetto R., Name K.P.O., Báo S.N., Campello C.C. \& Figueiredo J.R. 2012. Progesterone and Follicle Stimulating Hormone interact and promote goat preantral follicles survival and development in vitro. Pesquisa Veterinária Brasileira 32(4):361-367. Programa de Pós-Graduação em Ciências Veterinárias, Laboratório de Manipulação de Oócitos e Folículos Pré-Antrais, Universidade Estadual do Ceará, Av. Paranjana 1700, Campus do Itaperi, Fortaleza, CE 60740-000, Brazil. E-mail: isabel_limaverde@yahoo.com.br

We investigated the effects of progesterone and follicle stimulating hormone (FSH) on survival and growth of caprine preantral follicles. Pieces of ovarian tissue were cultured for 1 or 7 days in minimum essential medium (MEM) alone or containing progesterone (1, $2.5,5,10$ or $20 \mathrm{ng} / \mathrm{mL})$, FSH $(50 \mathrm{ng} / \mathrm{mL})$ or the interaction between progesterone and FSH. Fresh (non-cultured control) and cultured ovarian tissues were processed for histological and ultrastructural studies. After 7 days the addition of FSH to all progesterone concentrations maintained the percentage of normal follicles similar to fresh control. At day 7 of culture, a higher percentage of developing follicles was observed only in $2.5 \mathrm{ng} / \mathrm{ml}$ of progesterone associated with FSH or $10 \mathrm{ng} / \mathrm{ml}$ of progesterone alone when compared with control. From day 1 to day 7 of culture, a significant increase in the percentage of developing follicles was observed in MEM and $2.5 \mathrm{ng} / \mathrm{ml}$ of progesterone $+\mathrm{FSH}$. In addition, after 7 days, in all treatments, there was a significant increase in follicular diameter when compared with control, except for MEM alone and in $5 \mathrm{ng} / \mathrm{ml}$ of progesterone $+\mathrm{FSH}$ or $10 \mathrm{ng} / \mathrm{ml}$ of progesterone alone. Ultrastructural studies confirmed follicular integrity after 7 days of culture in $2.5 \mathrm{ng} / \mathrm{ml}$ of progesterone with FSH. In conclusion, this study demonstrated that the interaction between progesterone and FSH maintains ultrastructural integrity, stimulates primordial follicles activation and further growth of cultured caprine preantral follicles.
\end{abstract}

INDEX TERMS: Progesterone, follicle stimulating hormone, FSH, preantral follicles, goats.

RESUMO.- [Progesterona e Hormônio Folículo-Estimulante interagem e promovem a sobrevivência e o desenvolvimento in vitro de folículos pré-antrais caprinos.] Este trabalho verificou os efeitos da progesterona e do hormônio folículo-estimulante (FSH) na sobrevivência e no crescimento de folículos pré-antrais caprinos. Fragmen-

\footnotetext{
${ }^{1}$ Received on July 18, 2011.

Accepted for publication on January 23, 2012.

${ }^{2}$ Programa de Pós-Graduação em Ciências Veterinárias (PPGCV), Laboratório de Manipulação de Oócitos e Folículos Pré-Antrais (Lamofopa), Universidade Estadual do Ceará (UECE), Avenida Paranjana 1700, Campus do Itaperi, Fortaleza, CE 60740-000, Brazil. *Corresponding author: isabel_limaverde@yahoo.com.br

${ }^{3}$ Instituto de Biologia, Departamento de Biologia Celular, Laboratório de Microscopia Eletrônica, Universidade de Brasília (UnB), Brasília, DF 70910-900, Brazil.
}

tos de tecido ovariano foram cultivados por 1 ou 7 dias em Meio Essencial Mínimo (MEM) sozinho ou contendo progesterona $(1,2.5,5,10$ ou $20 \mathrm{ng} / \mathrm{mL}), \mathrm{FSH}(50 \mathrm{ng} / \mathrm{mL})$ ou a combinação entre esses dois hormônios. 0 tecido fresco (controle não-cultivado) e o cultivado foram processados para análise histológica e ultra-estrutural. Após 7 dias a adição de FSH a todas as concentrações de progesterone manteve o percentual de folículos normais similar ao controle fresco. No dia 7 de cultivo, um alto percentual de folículos em desenvolvimento foi observado somente no tratamento com $2,5 \mathrm{ng} / \mathrm{ml}$ de progesterona associada ao FSH ou com $10 \mathrm{ng} / \mathrm{ml}$ de progesterona sozinha, em relação ao controle fresco. Do dia 1 para o dia 7 de cultivo, um aumento significativo no percentual de folículos em desenvolvimento foi observado no MEM sozinho e adicionado de 2,5ng/ml de progesterona + FSH. Além disso, após 7 dias, 
em todos os tratamentos, houve um aumento significativo no diâmetro folicular em relação ao controle, exceto nos tratamentos com MEM sozinho, $5 \mathrm{ng} / \mathrm{ml}$ de progesterona + FSH ou $10 \mathrm{ng} / \mathrm{ml}$ de progesterona sozinha. A análise ultra-estrutural confirmou a integridade follicular após 7 dias de cultivo no tratamento com $2,5 \mathrm{ng} / \mathrm{ml}$ de progesterona + FSH. Em conclusão, este estudo demonstrou que a interação entre progesterona e FSH mantém a integridade ultra-estrutural, estimula a ativação de folículos primordiais e o posterior crescimento de folículos pré-antrais caprinos cultivados in vitro.

TERMOS DE INDEXAÇÃO: Progesterona, hormônio folículo-estimulante, FSH, folículo pré-antral, caprinos.

\section{INTRODUCTION}

In vitro follicle culture is an essential tool in understanding the mechanisms of oocyte growth and differentiation. Over recent years, various culture systems for preantral follicles have been developed in several species (Cecconi et al. 1999, Gutierrez et al. 2000, Matos et al. 2007a,b). Primordial follicles represent the earliest and the most abundant stage of ovarian follicles and consist of an oocyte surrounded by a single layer of flattened granulosa cells (Gougeon 1996). Mechanisms regulating the activation of follicles from the primordial through the primary stages of development are still limited. Because primordial follicles potentially represent a large source of oocytes in humans and large animals, with several possible applications, such as infertility treatment in clinical medicine or improvement of animal reproductive potential, efforts have been focused on developing culture systems for follicles at that stage. In addition, the in vitro culture of preantral follicles allows the evaluation of the effects of different substances (hormones, growth factors, antibiotics, etc) on the ovarian physiology before their use in vivo in animals or humans.

Steroid hormones, such as progesterone, are important in the reproductive processes of mammalian female. The ovary synthesizes progesterone, and its secretion is dependent on gonadotrophin stimulation and physiological state of the ovary (Peluso 2006). This hormone acts in follicular growth, ovulation and luteinization (Peluso 2006), besides prevents apoptosis in granulosa cells in human (Makrigiannakis et al. 2000) and mouse (Shao et al. 2003). The effects of progesterone in the ovary are carried out directly by their receptors (PRA and PRB). In caprine, the plasmatic physiological concentrations of progesterone alternate from 0.5 up to $13.3 \mathrm{ng} / \mathrm{ml}$ during estrous cycle (Menchaca and Rubianes 2002, Khanum et al. 2007). However, the effects of different physiological concentrations of progesterone are not yet tested in the in vitro culture of caprine preantral follicles, being important to verify if this hormone has any role in early folliculogenesis.

Some studies demonstrated that addition of FSH to the culture medium maintains viability and promotes in vitro growth of early caprine preantral follicles (Matos et al. 2007a), as well as antrum formation in different species after in vitro culture of large secondary follicles in mouse (Spears et al. 1998), murine (McGee et al. 1997), human (Wright et al. 1999), ovine (Cecconi et al. 1999), bovine (Gutierrez et al. 2000) and swine (Mao et al. 2002). In addition, FSH stimulates granulosa cells proliferation in swine (Hirao et al. 1994), inhibits apoptosis of granulosa cells cultured in vitro and increases progesterone secretion by these cells (Yu et al. 2003). Although FSH receptors are expressed in granulosa cells (O'Shaughnessy et al. 1996, Ulloa-Aguirre et al. 2003) from primary follicles stage onward (Oktay et al. 1997), this hormone may act indirectly in the primordial follicles through paracrine factors secreted by larger follicles or stroma cells. However, there are no reports demonstrating that the interaction between progesterone and FSH is able to promote follicular activation and growth of caprine preantral follicles.

The aim of this work is to verify whether physiological concentrations of progesterone alone or in association with FSH have a beneficial effect on the survival, activation and growth of caprine preantral follicles cultured in vitro for 1 or 7 days.

\section{MATERIALS AND METHODS}

Unless mentioned otherwise, the culture media, progesterone and other chemicals used in the present study were purchased from Sigma Chemical Co. (St Louis, USA).

Source of ovaries. Ovarian cortical tissues ( $\mathrm{n}=8$ ovaries) were collected at a local slaughterhouse from four adult (1-3 years old), mixed-breed goats. Immediately postmortem, the ovaries were washed in $70 \%$ alcohol for 10 seconds followed by two times in Minimum Essential Medium (MEM) supplemented with $100 \mu \mathrm{g} /$ $\mathrm{mL}$ penicillin and $100 \mu \mathrm{g} / \mathrm{mL}$ streptomycin. The pairs of ovaries were transported within 1 hour to the laboratory in $\mathrm{MEM}$ at $33^{\circ} \mathrm{C}$.

Experimental protocol. In the laboratory, the ovaries from each animal were stripped of surrounding fat tissue and ligaments and then, cut in half. The medulla, large antral follicles, and corpora lutea were removed. Our organ culture system was described in detail earlier (Matos et al. 2007a,b). Ovarian tissue samples from each ovarian pair were cut in 25 slices ( $3 \mathrm{~mm} \times 3 \mathrm{~mm}$ $\mathrm{x} 1 \mathrm{~mm}$ ) using a needle and scalpel under sterile conditions. The tissue pieces were then either directly fixed for histological and ultrastructural analysis (fresh control) or placed in culture for one or seven days. Caprine tissues were transferred to 24-well culture dishes containing $1 \mathrm{ml}$ of culture media. Culture was performed at $39^{\circ} \mathrm{C}$ in $5 \% \mathrm{CO}_{2}$ in a humidified incubator and all the media were incubated for $1 \mathrm{~h}$ prior to use. The basic culture medium (cultured control) consisted of MEM (pH 7.2-7.4) supplemented with ITS (insulin $6.25 \mathrm{ng} / \mathrm{mL}$, transferrin $6.25 \mathrm{ng} / \mathrm{mL}$ and selenium $6.25 \mathrm{ng} / \mathrm{mL}$ ), $0.23 \mathrm{mM}$ pyruvate, $2 \mathrm{mM}$ glutamine, $2 \mathrm{mM}$ hypoxantine, $1.25 \mathrm{mg} / \mathrm{mL}$ bovine serum albumin (BSA), which was called $\mathrm{MEM}^{+}$. Fragments were cultured in $\mathrm{MEM}^{+}$alone or $\mathrm{MEM}^{+}$containing progeterone $(1,2.5,5,10$ or $20 \mathrm{ng} / \mathrm{mL})$, FSH $(50 \mathrm{ng} / \mathrm{ml})$ or the interaction between different concentrations of progesterone and FSH (50ng/ml) (porcine FSH, provided by Dr. J.F. Beckers, Liège, Belgium), as shown in Table 1. Each treatment was repeated four times and the culture media was replenished every other day. The concentrations of progesterone were based on physiologic parameters for goats (Menchaca \& Rubianes 2002, Khanum et al. 2007), whereas the concentration of FSH was based on preliminary studies culturing caprine preantral follicles in our laboratory (Matos et al. 2007a).

Morphological analysis of preantral follicles. Before culture (fresh control) and after one or seven days in culture, all pieces were fixed in Carnoy's solution for $12 \mathrm{~h}$ and then dehydrated in increasing concentrations of ethanol. After paraffin embedding 
Table 1. Different media tested for the in vitro culture of caprine preantral follicles

\begin{tabular}{lc}
\hline \multicolumn{1}{c}{ Culture médium } & Abbreviation \\
\hline $\mathrm{MEM}^{+}$ & $\mathrm{MEM}^{+}$ \\
$\mathrm{MEM}^{+}+\mathrm{FSH}$ & $\mathrm{FSH}$ \\
$\mathrm{MEM}^{+}+$Progesterone $(1 \mathrm{ng} / \mathrm{ml})$ & $\mathrm{P} 1$ \\
$\mathrm{MEM}^{+}+$Progesterone $(1 \mathrm{ng} / \mathrm{ml})+\mathrm{FSH}$ & $\mathrm{P} 1 \mathrm{~F}$ \\
$\mathrm{MEM}^{+}+$Progesterone $(2.5 \mathrm{ng} / \mathrm{ml})$ & $\mathrm{P} 2.5$ \\
$\mathrm{MEM}^{+}+$Progesterone $(2.5 \mathrm{ng} / \mathrm{ml})+\mathrm{FSH}$ & $\mathrm{P} 2.5 \mathrm{~F}$ \\
$\mathrm{MEM}^{+}+$Progesterone $(5 \mathrm{ng} / \mathrm{ml})$ & $\mathrm{P} 5$ \\
$\mathrm{MEM}^{+}+$Progesterone $(5 \mathrm{ng} / \mathrm{ml})+\mathrm{FSH}$ & $\mathrm{P} 5 \mathrm{~F}$ \\
$\mathrm{MEM}^{+}+$Progesterone $(10 \mathrm{ng} / \mathrm{ml})$ & $\mathrm{P} 10$ \\
$\mathrm{MEM}^{+}+$Progesterone $(10 \mathrm{ng} / \mathrm{ml})+\mathrm{FSH}$ & $\mathrm{P} 10 \mathrm{~F}$ \\
$\mathrm{MEM}^{+}+$Progesterone $(20 \mathrm{ng} / \mathrm{ml})$ & $\mathrm{P} 20$ \\
$\mathrm{MEM}^{+}+$Progesterone $(20 \mathrm{ng} / \mathrm{ml})+\mathrm{FSH}$ & $\mathrm{P} 20 \mathrm{~F}$
\end{tabular}

(Synth, São Paulo, Brazil), the wax blocks containing the treatments were completely and serially sectioned ( $7 \mu \mathrm{m}$ sections), and every section was mounted on glass slides and stained by Periodic Acid Schiff - hematoxylin. Follicle stage and survival were assessed microscopically on serial sections. Coded anonymized slides were examined on a microscopy (Nikon, Japan) under 400x magnification.

The developmental stages of follicles have been defined previously (Silva et al. 2004) as primordial (one layer of flattened granulosa cells around the oocyte) or growing follicles (intermediate: one layer of flattened to cuboidal granulosa cells; primary: one layer of cuboidal granulosa cells, and secondary: two or more layers of cuboidal granulosa cells around the oocyte). These follicles were still classified individually as histologically normal when an intact oocyte was present, surrounded by granulosa cells which are well organized in one or more layers and that have no pyknotic nucleus. Atretic follicles were defined as those with a retracted oocyte, pyknotic nucleus, and disorganized granulosa cells detached from the basement membrane. Overall, 120 follicles were evaluated for each treatment ( 30 follicles per treatment in one repetition $\mathrm{x} 4$ repetitions $=120$ follicles).

To evaluate follicular activation, the percentages of healthy primordial and growing follicles were calculated before (fresh control) and after culture in each medium. In addition, follicle and oocyte diameters were measured only in healthy follicles. Follicle diameter was recorded from edge to edge of granulosa cell membrane, or from the outside edge of the theca cell layer when present. Oocyte diameter was recorded from edge to edge of the oocyte membrane. Two perpendicular diameters were recorded for each and the average of these two values was reported as follicle and oocyte diameters, respectively. Care was taken to count each follicle only once as we have also done in our earlier studies

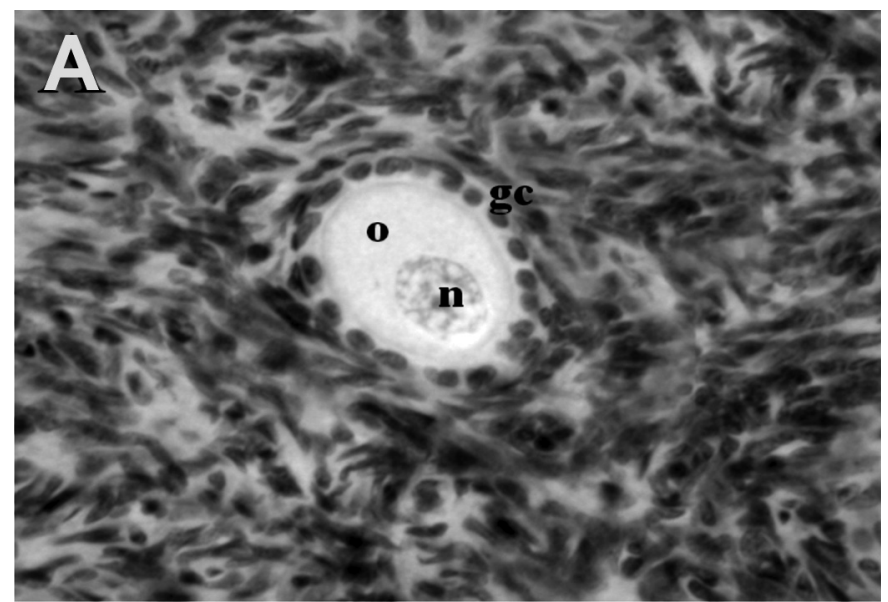

(Matos et al. 2007a,b). Each follicle was examined in every section in which it appeared and matched with the same follicle on adjacent sections to avoid double counting, thus ensuring that each follicle was only counted once, regardless of its size.

Ultrastructural analysis of preantral follicles. For better evaluation of the follicular morphology, ultrastructural studies were carried out on fragments $\left(1 \mathrm{~mm}^{3}\right)$ of fresh control and treatments that maintained follicular morphology during the histological analysis. Briefly, ovarian tissues were fixed in $2 \%$ paraformaldehyde and $2.5 \%$ glutaraldehyde in $0.1 \mathrm{M}$ sodium cacodylate buffer ( $\mathrm{pH}$ 7.2) for $4 \mathrm{~h}$ at room temperature. After fixation, fragments were post-fixed in $1 \%$ osmium tetroxide, $0.8 \%$ potassium ferricyanide and $5 \mathrm{mM}$ calcium chloride in $0.1 \mathrm{M}$ sodium cacodylate buffer for $1 \mathrm{~h}$. Subsequently, the samples were dehydrated through a gradient of acetone solutions and the tissues were embedded in Spurr. Semi thin sections $(3 \mu \mathrm{m})$ were cut on an ultramicrotome (Reichert Supernova, Heidelberg, German) for light microscopy studies and stained with toluidine blue. The ultra-thin sections $(60-70 \eta \mathrm{m})$ were contrasted with uranyl acetate and lead citrate, and examined under a Jeol 1011 (Jeol, Tokyo, Japan) transmission electron microscope operating at $80 \mathrm{kV}$. Parameters such as density and integrity of ooplasmic and granulosa cell organelles, vacuolization and basement membrane integrity were evaluated.

Statistical analysis. Data were analyzed statistically with Kolmogorov-Smirnov and Bartlett's tests, which were applied to confirm normal distribution and homogeneity of variance, respectively. Analysis of variance was made using GLM procedure of SAS (1999) and Dunnett's test was applied for comparison of control group against each treatment tested. Student Newman Keuls' (SNK) test was used to compare percentages of surviving primordial or developing follicles among treatments and days of culture. Because of the higher coefficient of variation observed in some comparisons, Duncan's test was applied to compare treatments tested, whilst Student's t-test was used to compare means between days of culture. Differences among groups were considered significant when $\mathrm{P}<0.05$ and results were expressed as mean \pm standard deviation (SD).

\section{RESULTS}

Caprine preantral follicle survival after in vitro culture

A total of 3,000 preantral follicles were analyzed by classical histology, which showed morphologically normal and degenerated follicles before (non-cultured control) and after in vitro culture for 1 or 7 days. In degenerated follicles, histological changes such as cytoplasmic retraction, picnotic nucleus and disorganized granulosa cells were observed (Fig.1).

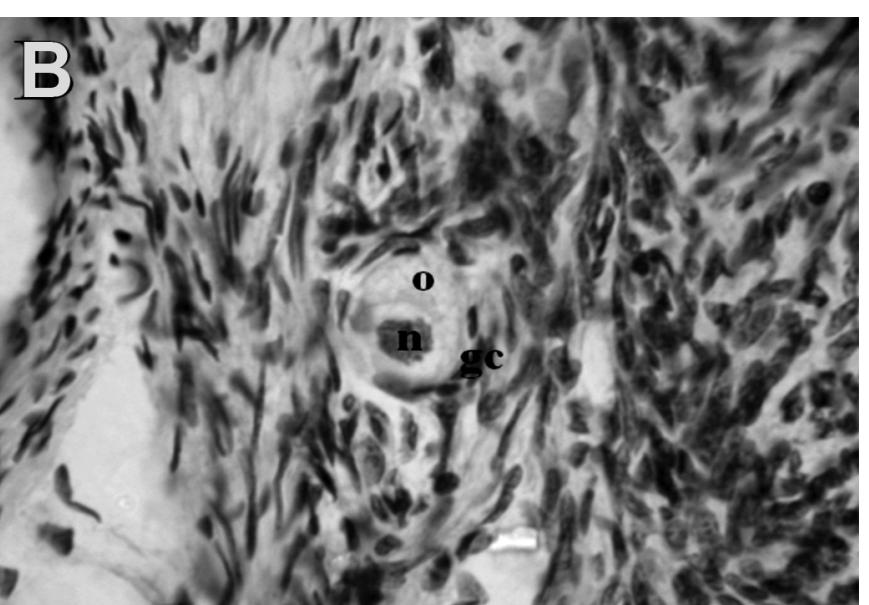

Fig.1. Histological section (400x) of preantral follicles cultured for 7 days with FSH plus progesterone (2.5ng/ml) (A) and MEM+ (B) showing (n) nucleus, (gc) granulosa cell, (o) oocyte. Note cytoplasmic retraction and picnotic nucleus in Figure B. 
The percentages of histologically normal preantral follicles in control (fresh tissue) and after 1 or 7 days of culture are shown in Table 2. After 1 day, it was observed a significant reduction $(\mathrm{P}<0.05)$ in the percentage of normal follicles after culture with 2.5 or $10 \mathrm{ng} / \mathrm{ml}$ of progesterone alone, compared with fresh control. In the same period, the association of $2.5 \mathrm{ng} / \mathrm{ml}$ of progesterone $+\mathrm{FSH}$ was benefic to the culture, since it showed greater $(\mathrm{P}<0.05)$ percentage of normal follicles in relation to the same concentration of progesterone alone. At day 7 of culture, addition of FSH to all progesterone concentrations kept the percentage of histologically normal preantral follicles similar to fresh control $(\mathrm{P}>0.05)$. It was not observed any significant difference in the percentage of normal follicles between other treatments and $\mathrm{MEM}^{+}$at day 1 or $7(\mathrm{P}>0.05)$

Table 2. Percentages of morphologically normal caprine preantral follicles in control (non-cultured tissue) and after 1 or 7 days of culture in medium containing progesterone and/or FSH

\begin{tabular}{ccc}
\hline Control & \multicolumn{2}{c}{$85.02 \pm 4.30 \%$} \\
\cline { 2 - 3 } & Day $1(\%)$ & Day $7(\%)$ \\
\hline MEM & $68.37 \pm 12.32^{\mathrm{c}}$ & $59.17 \pm 6.88^{* \mathrm{c}}$ \\
FSH & $69.20 \pm 11.98^{\mathrm{c}}$ & $57.52 \pm 16.61^{* \mathrm{ac}}$ \\
P1 & $70.87 \pm 12.87^{\mathrm{ac}}$ & $56.70 \pm 14.40^{* \mathrm{ac}}$ \\
P1F & $69.20 \pm 9.17^{\mathrm{ac}}$ & $68.37 \pm 10.38^{\mathrm{ac}}$ \\
P2.5 & $49.17+13.44^{* \mathrm{ac}}$ & $58.35+8.38^{* \mathrm{ac}}$ \\
P2.5F & $71.70 \pm 5.77^{\mathrm{bc}}$ & $64.20 \pm 9.95^{\mathrm{ac}}$ \\
P5 & $70.85 \pm 8.34^{\mathrm{ac}}$ & $60.85 \pm 10.31^{* \mathrm{ac}}$ \\
P5F & $70.85 \pm 14.24^{\mathrm{ac}}$ & $64.20 \pm 7.41^{\mathrm{ac}}$ \\
P10 & $58.37 \pm 15.49^{* \mathrm{ac}}$ & $58.35 \pm 6.95^{* \mathrm{ac}}$ \\
P10F & $70.85+15.50^{\mathrm{ac}}$ & $63.37+6.65^{\mathrm{ac}}$ \\
P20 & $69.20 \pm 9.57^{\mathrm{ac}}$ & $56.70 \pm 16.77^{* \mathrm{ac}}$ \\
P20F & $79.20 \pm 4.19^{\mathrm{ac}}$ & $62.52 \pm 15.22^{\mathrm{ac}}$
\end{tabular}

* Differs significantly from control follicles $(\mathrm{P}<0.05)$.

a,b Differs significantly from addition of FSH at the same concentrations and days of culture $(\mathrm{P}<0.05)$

c,d Differs significantly between days of culture in the same treatment $(\mathrm{P}<0.05)$.

\section{Activation of caprine primordial follicles after in vitro culture}

At day 1 of culture, $2.5 \mathrm{ng} / \mathrm{ml}$ of progesterone alone or $20 \mathrm{ng} / \mathrm{ml}$ of progesterone associated with FSH significantly increased $(\mathrm{P}<0.05)$ the percentage of growing follicles when compared with fresh control (Fig.2). After 7 days, a significant increase $(\mathrm{P}<0.05)$ of growing follicles was observed with $2.5 \mathrm{ng} / \mathrm{ml}$ of progesterone $+\mathrm{FSH}$ or $10 \mathrm{ng} / \mathrm{ml}$ of progesterone alone, compared with fresh control. At day 1 , the media containing 1 and $2.5 \mathrm{ng} / \mathrm{ml}$ of progesterone alone and $20 \mathrm{ng} / \mathrm{ml}$ of progesterone + FSH showed significantly higher percentage of follicular activation than $\mathrm{MEM}^{+}$alone $(\mathrm{P}<0.05)$. It is important to note that from days 1 to 7 , there was a significant reduction $(20 \mathrm{ng} / \mathrm{ml}$ of progesterone $+\mathrm{FSH})$ and, in some treatments, an increase $\left(\mathrm{MEM}^{+}\right.$alone and $2.5 \mathrm{ng} / \mathrm{ml}$ of progesterone $+\mathrm{FSH}$ ) in the percentage of growing follicles $(\mathrm{P}<0.05)$.

\section{In vitro growth of caprine preantral follicles}

After 1 day of culture, there was a significant increase $(\mathrm{P}<0.05)$ in follicular diameter in $\mathrm{MEM}^{+}$or $\mathrm{MEM}^{+}$supplemented with $2.5,10$ and $20 \mathrm{ng} / \mathrm{ml}$ of progesterone plus FSH,

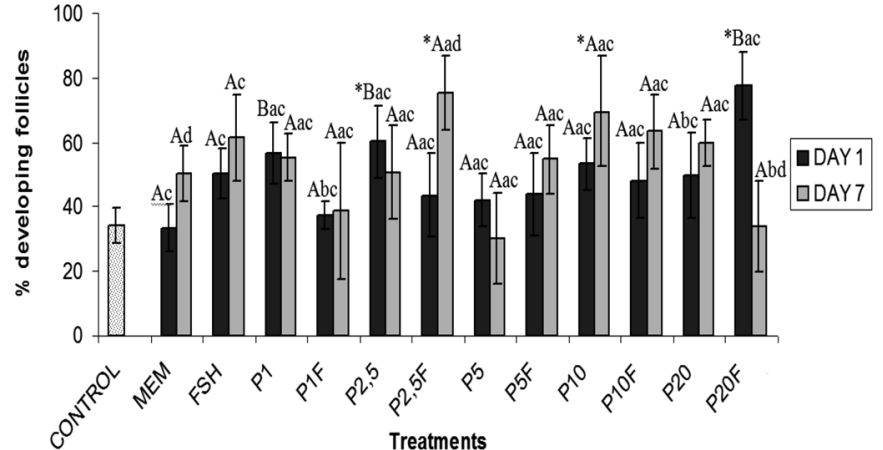

Fig.2. Percentages of developing preantral follicles in control (non-cultured tissue) and after 1 or 7 days of culture in medium containing progesterone and/or FSH.

or 5 and $10 \mathrm{ng} / \mathrm{ml}$ of progesterone alone, compared with fresh control (Fig.3). After 7 days, in all treatments, there was a significant increase $(\mathrm{P}<0.05)$ in follicular diameter in all treatments compared with fresh control, except in $\mathrm{MEM}^{+}$ and $\mathrm{MEM}^{+}$when $5 \mathrm{ng} / \mathrm{ml}$ of progesterone + $\mathrm{FSH}$ or 10ng/ $\mathrm{ml}$ of progesterone alone. When FSH was added to the medium containing progesterone $(2.5,10$ and $20 \mathrm{ng} / \mathrm{ml})$, follicular diameter significantly increased $(\mathrm{P}<0.05)$ when compared with these same concentrations alone, after 1 day, while its addition decreased follicular diameter in $5 \mathrm{ng} / \mathrm{ml}$ of progesterone plus FSH $(\mathrm{P}<0.05)$. At day 7 of culture, the positive effect of FSH addition was verified at the concentration of $10 \mathrm{ng} / \mathrm{ml}$ of progesterone $(\mathrm{P}<0.05)$. With the progression of the culture period from 1 to 7 days, there was a significant increase $(\mathrm{P}<0.05)$ in follicular diameter in $\mathrm{FSH}$,

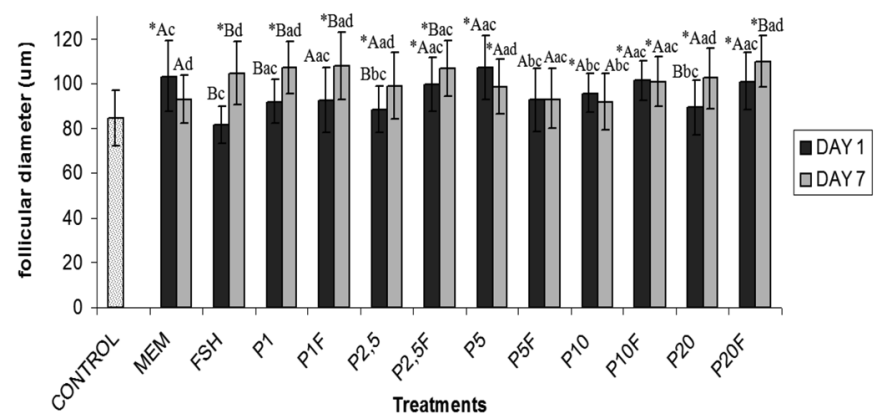

Fig.3. Mean follicular diameter $(\mu \mathrm{m})$ in the control (non-cultured tissue) and after 1 or 7 days of culture in medium containing progesterone and/or FSH.

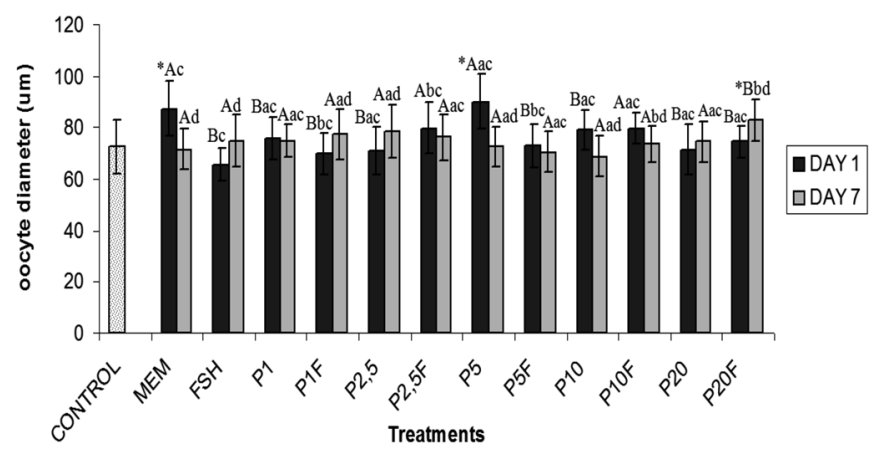

Fig.4. Mean oocyte diameter $(\mu \mathrm{m})$ in the control (non-cultured tissue) and after 1 or 7 days of culture in medium containing progesterone and/or FSH. 

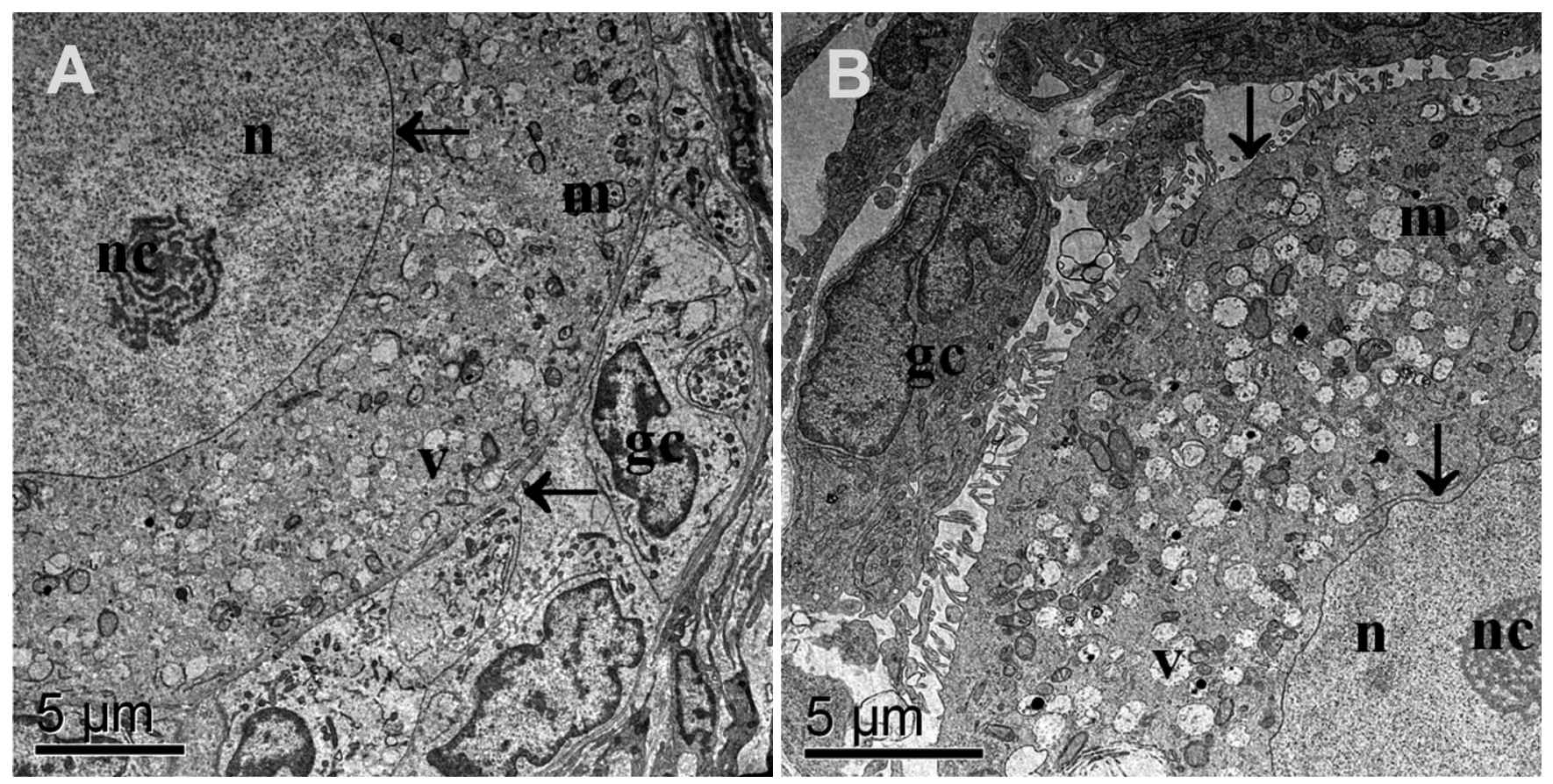

Fig.5. Ultrastructural analysis of non cultured preantral follicle (A) (5000x) and cultured for 7 days in medium containing FSH plus progesterone $(2.5 \mathrm{ng} / \mathrm{ml})$ (B) (6000x) showing (n) nucleus, (gc) granulosa cell, (nc) nucleolus, (m) mitochondria, (arrows) nuclear and oocyte membranes. Note intact oocyte and nuclear membranes, nucleus with descondensed chromatin, granulosa cells with elongated nucleus and a high proportion nucleus-cytoplasm.

progesterone alone $(1,2.5$ and $20 \mathrm{ng} / \mathrm{ml})$ and progesterone (1 and $20 \mathrm{ng} / \mathrm{ml}$ ) plus FSH, and a decrease in this diameter for culture performed with MEM+ or MEM+ supplemented with $5 \mathrm{ng} / \mathrm{ml}$ of progesterone $(\mathrm{P}<0.05)$.

At day 1 of culture, $\mathrm{MEM}^{+}$or $\mathrm{MEM}^{+}$supplemented with $5 \mathrm{ng} / \mathrm{ml}$ of progesterone promoted an increase $(\mathrm{P}<0.05)$ in oocyte diameter when compared to fresh control (Fig.4). However, after 7 days, only $20 \mathrm{ng} / \mathrm{ml}$ of progesterone associated with FSH showed an oocyte diameter significantly higher than control or $\mathrm{MEM}^{+}$. Moreover, addition of FSH to $2.5 \mathrm{ng} / \mathrm{ml}$ of progesterone was benefic to preantral follicles, since it was the only treatment that promoted an increase in oocyte diameter after 1 day of culture $(\mathrm{P}<0.05)$. After 7 days, the same effect was observed with 10 or $20 \mathrm{ng} / \mathrm{ml}$ of progesterone. With the progression of the culture period from 1 to 7 days, it was observed a significant reduction $(\mathrm{P}<0.05)$ in the oocyte diameter with $\mathrm{MEM}^{+}$or $\mathrm{MEM}^{+}$supplemented with 5 or $10 \mathrm{ng} / \mathrm{ml}$ of progesterone alone or in $10 \mathrm{ng} / \mathrm{ml}$ of progesterone $+\mathrm{FSH}$. In contrast, in such period, it was observed a significant increase in oocyte diameter in $\mathrm{MEM}^{+}$supplemented with FSH, $2.5 \mathrm{ng} / \mathrm{ml}$ of progesterone alone and progesterone ( 1 and $20 \mathrm{ng} / \mathrm{ml})+\mathrm{FSH}$.

\section{Ultrastructural analysis of cultured caprine preantral follicles}

For a better evaluation of follicular integrity, the ultrastructural analysis was performed in tissues from fresh control as well as in those cultured for 7 days with $2.5 \mathrm{ng} / \mathrm{ml}$ of progesterone, which showed satisfactory results at histological evaluation. Both treatments showed ultrastructurally normal follicles (Fig.5), with intact oocyte and nuclear membranes, nucleus with descondensed chromatin, some vesicles and organelles uniformly distributed in the cytoplasm. The granulosa cells were normal, with elongated nucleus and a high proportion nucleus-cytoplasm.

\section{DISCUSSION}

The present study showed the influence of progesterone on the survival, activation and growth of caprine preantral follicles cultured in vitro. It is important to emphasize that the concentrations of progesterone used in this study were similar to the physiological levels reported in caprine specie (Menchaca \& Rubianes 2002, Khanum et al. 2007).

After 7 days of culture, it was observed that addition of FSH to all concentrations of progesterone kept the percentage of preantral follicles similar to fresh control, which demonstrate a positive interaction between these two hormones. Although there were few studies regarding the influence of progesterone associated with FSH on preantral follicles culture, it is known that this steroid can prevent granulosa cells apoptosis in human (Makrigiannakis et al. 2000) and mouse (Shao et al. 2003). Furthermore, some studies demonstrated the importance of FSH for the maintenance of preantral follicle viability (Cortvrindt et al. 1997, Matos et al. 2007a), inhibition of apoptosis of caprine granulosa cells from antral follicles, as well as increasing progesterone secretion by these cells (Yu et al. 2003).

In this study, after 7 days of culture, it was verified a greater percentage of growing preantral follicles with $2.5 \mathrm{ng} /$ $\mathrm{ml}$ of progesterone associated with FSH or $10 \mathrm{ng} / \mathrm{ml}$ of progesterone alone, compared to fresh tissue. Progesterone is a steroid hormone synthesized by the ovary, and its secre- 
tion is dependent on gonadotrophin stimulation and physiological state of the ovary (Peluso et al. 2006). LH stimulates the conversion of cholesterol to progesterone in theca cells. Thus, progesterone will be converted to testosterone (still in theca cells), and the latter converted to estradiol in the granulosa cells under FSH influence. Estradiol acts increasing progesterone production, until it reaches high seric levels and then decreases FSH action on granulosa cells and consequently estradiol production (Yarak et al. 2005). In this manner, we can suppose that the action of these two hormones is related and could have influenced the results obtained in this work. Some studies demonstrated that progesterone acts in follicular growth, ovulation and luteinization (Peluso et al., 2006), besides promotes in vitro maturation of monkeys (Zheng et al. 2003) and bitches (Kim et al. 2005, Vannucchi et al. 2006) oocytes. Furthermore, FSH can promote in vitro follicular activation in ovine (Andrade et al. 2005) and bubaline (Santos et al. 2006), acting indirectly in the ovary, regulating growth factors that promote primordial follicle development (Thomas et al. 2005).

After 7 days, in all treatments tested, follicular diameter was larger than fresh control, except when $5 \mathrm{ng} / \mathrm{ml}$ of progesterone + FSH or $10 \mathrm{ng} / \mathrm{ml}$ of progesterone alone were used. In the same period, the concentration of $20 \mathrm{ng} / \mathrm{ml}$ of progesterone in association with FSH showed an oocyte diameter larger than control and $\mathrm{MEM}^{+}$alone. The effect of progesterone in the ovary are exerted by their receptors (PRA and PRB) present in theca and granulosa cells of preantral and antral follicles in mouse (Gava et al. 2004), swine (Slomczynska et al. 2000) and bovine (D'Haeseleer et al. 2007) and these receptors increase progressively in conformity with follicular development. However, it was demonstrated that in mouse without progesterone receptors (PRA and PRB), follicular development can normally occurs (Lydon et al. 1996), suggesting that other receptors can be involved in progesterone action. Regarding FSH, their receptors are expressed in granulosa cells from primary follicles stage onward (Xu et al. 1995, O'Shaughnessy et al. 1996), suggesting that this hormone have an important role in follicular growth.

In this study, TEM was performed in fresh control and in the treatment with $2.5 \mathrm{ng} / \mathrm{ml}$ of progesterone associated with FSH. Follicles were ultrastructurally normal with their features similar to those observed previously in caprine preantral follicles cultured in vitro for up to 7 days (Matos et al. 2007a,b).

In conclusion, this study demonstrated that the association of $2.5 \mathrm{ng} / \mathrm{ml}$ of progesterone with $50 \mathrm{ng} / \mathrm{ml}$ of FSH could promote caprine primordial follicles activation, as well as further in vitro follicular growth. In addition, the results showed that the interaction between these hormones maintain ultrastructural integrity of caprine preantral follicles cultured in vitro for up to 7 days. This culture system should be useful for studying the regulation of early follicular growth and development, especially because these follicles represent a large source of oocytes that could be used in vitro for embryo production.

Acknowledgements.- This work was supported by CNPq (Renorbio). Isabel B. Lima-Verde is a recipient of a grant from Funcap/CAPES (Fortale- za, Ceará, Brazil). We would like to acknowledge the generous donation of pFSH by Dr Jean-François Beckers of the University of Liége, Belgium, and the special contribution of Sarah Bezerra Honório and Jamily Bezerra Bruno.

\section{REFERENCES}

Andrade E.R, Seneda M.M., Alfieri A.A., Oliveira J.A., Bracarense A.P.F.R.L., Figueiredo J.R. \& Toniolli R. 2005. Interactions of indole acetic acid with EGF and FSH in the culture of ovine preantral follicles. Theriogenology 64:1104-1113.

Cecconi S., Barboni B., Coccia M. \& Mattioli M. 1999. In vitro development of sheep preantral follicles. Biol. Reprod. 60:594-601.

Cortvrindt R., Smitz J. \& Van Steirteghem A.C. 1997. Assessment of the need for follicle stimulating hormone in early preantral mouse follicle culture in vitro. Hum. Reprod. 12:759-768.

D’Haeseleer M., Simoens P. \& Van den Broeck W. 2007. Cell-specific localization of progesterone receptors in the bovine ovary at different stages of the oestrous cycle. Anim. Reprod. Sci. 98:271-281.

Gava N., Clarke C.L., Byth K., Arnett-Mansfield R.L. \& Fazio A. 2004. Expression of progesterone receptors $A$ and $B$ in the mouse ovary during the estrous cycle. Endocrinology 145:3487-3494.

Gougeon A. 1996. Regulation of ovarian follicular development in primates: Facts and hypothesis. Endocr. Rev. 17:121-154.

Gutierrez C.G., Ralph J.H., Telfer E.E., Wilmut I. \& Webb R. 2000. Growth and antrum formation of bovine preantral follicles in long-term culture in vitro. Biol. Reprod. 62:1322-1328.

Hirao Y., Nagai T., Kubo M., Miyano T., Miyake M. \& Kato S. 1994. In vitro growth and maturation of pig oocytes. J. Reprod. Fertil.100:333-339.

Khanum S.A., Hussain M. \& Kausar R. 2007. Assessment of reproductive parameters in female Dwarf goat (Capra hircus) on the basis of progesterone profiles. Anim. Reprod. Sci. 102:267-275.

Kim M.K., Fibrianto Y.H., Oh H.J., Jang G., Kim H.J., Lee K.S., Kang S.K. \& Hwang W.S. 2005. Effects of estradiol-17 $\beta$ and progesterone supplementation on in vitro nuclear maturation of canine oocytes. Theriogenology 63:1342-1353.

Lydon J.P., DeMayo F.J., Conneely O.M. \& O'Malley B.W. 1996. Reproductive phenotypes of the progesterone receptor null mutant mouse. J. Steroid. Biochem. Mol. Biol. 56:67-77.

Makrigiannakis A., Coukos G., Christofidou-Solomidou M., Montas S. \& Coutifaris C. 2000. Progesterone is an autocrine/paracrine regulator of human granulosa cell survival in vitro. Ann. N.Y. Acad. Sci. 900:16-25.

Mao J., Wu G., Smith M.F., McCauley T.C., Cantley T.C., Prather R.S., Didion B.A. \& Day B.N. 2002. Effects of culture medium, serum type and various concentrations of follicle-stimulating hormone on porcine preantral follicular development and antrum formation in vitro. Biol. Reprod. 67:1197-1203.

Matos M.H.T., Lima-Verde I.B., Luque M.C.A., Maia Jr J.E., Silva J.R.V., Celestino J.J.H., Martins F.S., Báo S.N., Lucci C.M. \& Figueiredo JR. 2007a. Essential role of follicle stimulating hormone in the maintenance of caprine preantral follicle viability in vitro. Zygote 15:173-182.

Matos M.H.T., Van den Hurk R., Lima-Verde I.B., Luque M.C.A., Santos K.D.B., Martins F.S., Báo S.N., Lucci C.M. \& Figueiredo J.R. 2007b. Effects of fibroblast growth factor- 2 on the in vitro culture of caprine preantral follicles. Cells Tissues Organs 186:112-120.

McGee E., Spears N., Minami S., Hsu S.Y., Chun S.Y., Billig H. \& Hsueh A.J.W. 1997. Preantral ovarian follicles in serum-free culture: suppression of apoptosis after activation of the cyclic guanosine 3-5-monophosphate pathway and stimulation of growth and differentiation by follicle-stimulating hormone. Endocrinology 138:2417-2424.

Menchaca A. \& Rubianes E. 2002. Relation between progesterone concentrations during the early luteal phase and follicular dynamics in goats. Theriogenology 57:1411-1419.

Oktay K., Briggs D. \& Gosden R.G. 1997. Ontogeny of follicle-stimulating hormone receptor gene expression in solated human ovarian follicles. J. Clin. Endocrinol. Metab. 82:3748-3751. 
O’Shaughnessy P.J., Dudley K. \& Rajapaksha W.R. 1996. Expression of follicle stimulating hormone-receptor mRNA during gonadal development. Mol. Cell. Endocrinol. 125:169-175.

Peluso J.J. 2006. Multiplicity of progesterone's actions and receptors in the mammalian ovary. Biol. Reprod. 75:2-8.

Santos S.S.D., Biondi F.C., Cordeiro M.S., Miranda M.S., Dantas J.K., Figueiredo J.R. \& Ohashi O.M. 2006. Isolation, follicular density, and culture of preantral follicles of buffalo fetuses of different ages. Anim. Reprod. Sci. 95:1-15.

Shao R., Markstrom E., Friberg P.A., Johansson M. \& Billig H. 2003. Expression of progesterone receptor (PR) A and B isoforms in mouse granulosa cells: stage-dependent PR-mediated regulation of apoptosis and cell proliferation. Biol. Reprod. 68:914-921.

Silva J.R.V., Van den Hurk R., Costa S.H.F., Andrade E.R., Nunes A.P.A., Ferreira F.V.A., Lôbo R.N.B. \& Figueiredo J.R. 2004. Survival and growth of goat primordial follicles after in vitro culture of ovarian cortical slices in media containing coconut water. Anim. Reprod. Sci. 81:273-286.

Slomczynska M., Krok M. \& Pierscinski A. 2000. Localization of the progesterone receptor in the porcine ovary. Acta Histochemica 102:183-191.

Spears N., Murray A.A., Alisson V., Boland N.I. \& Gosden R.G. 1998. Role of gonadotro.ns and ovarian steroids in the development of mouse follicles in vitro. J. Reprod. Fertil. 113:19-26.

Thomas F.H., Ethier J.F., Shimasaki S. \& Vanderhyden B.C. 2005. Follicle-Stimulating Hormone regulates oocyte growth by modulation of expression of oocyte and granulosa cell factors. Endocrinology 146:941949.
Ulloa-Aguirre A., Timossi C., Barrios-de-Tomasi J., Maldonado A. \& Nayudu P. 2003. Impact of carbohydrate heterogeneity in function of FSH: Studies derived from in vitro and in vivo models. Biol. Reprod. 69:379-389.

Vannucchi C.I., Oliveira C.M., Marques M.G., Assumpção M.E.O.A. \& Visitin J.A. 2006. In vitro canine oocyte nuclear maturation in homologous oviductal cell co-culture with hormone-supplemented media. Theriogenology 66:1677-1681.

Wright C.S., Hovatta O., Margara R., Trew G., Winston R.M.L., Franks S. \& Hardy K. 1999. Effects of follicle-stimulating hormone and serum substitution on the in-vitro growth of human ovarian follicles. Hum. Reprod.14:1555-1562.

Xu Z., Garverick H.A., Smith G.W., Smith M.F., Hamilton S.A. \& Youngquist R.S. 1995. Expression of follicle-stimulating hormone and luteinizing hormone receptor messenger ribonucleic acids in bovine follicles during the first follicular wave. Biol. Reprod. 53:951-957.

Yarak S., Parada M.O.A.B., Bagatin E., Talarico-Filho S., Hassun K.M. 2005. Hiperandrogenismo e pele: síndrome do ovário policístico e resistência periférica à insulina. Anais Bras. Dermatol. 80:395-410.

Yu Y., Li W., Han Z., Luo M., Chang Z. \& Tan J. 2003. The effect of follicle-stimulating hormone on follicular development, granulosa cell apoptosis and steroidogenesis an its mediation by insulin-like growth factor-I in the goat ovary. Theriogenology 60:1691-1704.

Zheng P., Si W., Barry D.B., Yang J., Ding C. \& Ji W. 2003. 17ß-estadiol and progesterone improve in-vitro cytoplasmic maturation of oocytes from unstimulated prepubertal and adult rhesus monkeys. Hum. Reprod. 18:2137-2144. 